\title{
Pecanex-Like Protein 2
}

National Cancer Institute

\section{Source}

National Cancer Institute. Pecanex-Like Protein 2. NCI Thesaurus. Code C148622.

Pecanex-like protein 2 (2137 aa, $237 \mathrm{kDa}$ ) is encoded by the human PCNX2 gene. This protein may play a role in tumorigenesis, Notch signaling and cell cycle regulation. 